\title{
Increased DNA and/or RNA content of synovial fluid cells in rheumatoid arthritis: a flow-cytometry study
}

\author{
B. BONVOISIN ${ }^{1,2}$ G. CORDIER, ${ }^{1} \mathrm{~J} . \mathrm{P}$. REVILLARD, ${ }^{1}$ E. LEJEUNE, ${ }^{2}$ AND \\ M. BOUVIE ${ }^{2}$ \\ From the ${ }^{1}$ Centre de Cytofluorométrie, Unité INSERM U.80, Hôpital E. Herriot, Pavillon P, 69374 Lyon \\ Cedex 08, France; and the ${ }^{2}$ Service de Rhumatologie, Hôpital des Charpennes, 27 Grande rue des Charpennes, \\ 69100 Villeurbanne, France
}

SUMMARY Flow-cytometry studies of DNA and RNA content were carried out in acridine orange-stained synovial fluid lymphocytes from 11 patients presenting with classical or definite rheumatoid arthritis. Monoclonal antibodies were used to detect specific $\mathrm{T}$ cell surface antigens (OKT3, OKT4, OKT8) and antigens associated with lymphocyte activation (OKIa 1, OKT10). T3 positive cell percentages were comparable to those of normal blood, although T4/T8 ratios were decreased in 4 out of 5 cases, and HLA-DR positive cells increased. Six out of 11 patients showed percentages of dividing cells varying from $2 \cdot 2$ to $7 \cdot 2 \%$ as compared with less than $1 \%$ in the other patients and in normal blood. Nondividing cells were characterised by an increase in their RNA content compared with normal blood. A greater increase of RNA content was observed in patients with lower percentages of dividing cells, suggesting a G1/S block. Changes in cellular DNA and/or RNA contents provide a valuable parameter of lymphocyte activation, not necessarily linked to the expression of differentiation antigens by activated cells.

Numerous studies have provided evidence which suggests a major role of cell-mediated immune responses in the pathogenesis of rheumatoid arthritis (RA). Abnormalities of both $B$ and $T$ cell subsets have been described. B cell hyperactivity accounts for an excessive immunoglobulin production and formation of autoantibodies such as rheumatoid factors (RF). An imbalance of $T$ cell subsets has been reported in blood, ${ }^{1}$ synovial membrane, ${ }^{2}$ and cell suspensions prepared from synovial fluid. ${ }^{1,3}$ However, the results of functional studies remain controversial, though impairment of $T$ suppressive function of blood or synovial fluid lymphocytes from patients with rheumatoid arthritis has been reported.$^{4-6}$ Recently, immunohistological studies on biopsies from normal lymph nodes and rheumatoid synovial membranes led to the hypothesis of a defect in $\mathrm{T}$ lymphocyte-macrophage immunoregulation ${ }^{2}$ within the synovial membrane. Following stimulation, $\mathrm{T}$ cells may become activated and proliferate,

Accepted for publication 10 June 1983.

Correspondence to $\mathrm{Dr}$ G. Cordier, Centre de cytofluorométrie, Unité INSERM U.80, Hôpital E. Herriot, Pavillon P, 69374 Lyon Cedex 08, France. expressing new membrane markers such as HLA-DR antigens or antigens reacting with the OKT10 antibody. ${ }^{7}$

Cytofluorometry allows the distinction between proliferating cells characterised by their increased DNA content, and activated-nonproliferative cells characterised by their increased RNA content. The present study was undertaken to determine the respective proportions of proliferating and activated cells in synovial fluids from patients presenting with RA of various durations and stages of activity.

\section{Materials and methods}

Patients. Eleven adult patients ( 9 women and 2 men; age range $16-80$ years) presenting with classical or definite RA, according to the American Rheumatism Association (ARA) criteria, ${ }^{8}$ were studied. Disease duration varied from 18 months to 35 years. Disease activity was clinically assessed in accordance with the Steinbrocker functional and radiological stages: 1 patient belonged to class I, 5 to class II, and 5 to class III. One patient had signs of systemic vasculitis and 2 had subcutaneous nodules. 
Table 1 Biological parameters from 11 patients presenting with $R A$

\begin{tabular}{|c|c|c|c|c|c|c|c|}
\hline Patient & Sex & Age & $\begin{array}{l}E S R \\
(\mathrm{~mm} / \mathrm{h})\end{array}$ & $\begin{array}{l}A N A \\
(I F)\end{array}$ & $\begin{array}{l}C I C \\
(C I q B A)\end{array}$ & $\begin{array}{l}\text { Latex } \\
\text { (titre) }\end{array}$ & $\begin{array}{l}W \cdot R \\
\text { (titre) }\end{array}$ \\
\hline 1 & $F$ & 46 & 48 & 0 & & 0 & 0 \\
\hline 2 & $F$ & 60 & 112 & 0 & $50 \cdot 5$ & 3200 & 64 \\
\hline 3 & $\mathrm{~F}$ & 80 & 87 & 1024 & 8.0 & 200 & 8 \\
\hline 4 & $\mathbf{F}$ & 27 & 106 & 0 & $11 \cdot 0$ & & 32 \\
\hline 5 & $\mathbf{F}$ & 64 & 142 & 0 & $51 \cdot 5$ & 1600 & 128 \\
\hline 6 & $\mathbf{M}$ & 72 & 110 & 0 & 30.7 & 1280 & 256 \\
\hline 7 & $\mathbf{F}$ & 54 & 78 & 256 & $3 \cdot 4$ & 0 & 0 \\
\hline 8 & $F$ & 67 & 91 & 64 & $2 \cdot 5$ & 0 & 0 \\
\hline 9 & $\mathrm{~F}$ & 16 & $11 / 24$ & 0 & $2 \cdot 3$ & 0 & 0 \\
\hline 10 & $\mathbf{F}$ & 73 & 127 & 0 & 64 & 3200 & 64 \\
\hline 11 & $\mathbf{M}$ & 57 & 85 & 4096 & $10 \cdot 4$ & 800 & 32 \\
\hline
\end{tabular}

ESR $=$ erythrocyte sedimentation rate. ANA $=$ antinuclear antibodies. $\mathrm{IF}=$ immunofluorescence. $\mathrm{CIC}=$ circulating immune complexes. C1q BA $=$ C1q binding assay. W-R $=$ Waaler-Rose reaction.

The following biological parameters were recorded: erythrocyte sedimentation rate (ESR) expressed in millimetres in the first hour; antinuclear antibodies (ANA) measured by an indirect immunofluorescence technique on rat liver sections; circulating immune complexes (CIC) measured by a $\mathrm{Clq}$ binding assay and subsequent precipitation with polyethylene glycol; RF detected by the latex test and the Waaler-Rose reaction. Values of these different parameters are recorded in Table 1.

At the time of evaluation all patients were treated with nonsteroidal anti-inflammatory drugs alone. Four of them had also received immunomodulating agents (gold salts-patients 5 and 9; D-penicillamine-patients 6 and 11) more than one year before.

Preparation of cell suspensions. Synovial fluids were drawn aseptically, without the use of any anaesthetic agents, into heparinised tubes. They were treated with hyaluronidase (Laboratoire Choay, Paris, 250 units $/ 10 \mathrm{ml}$ ) for 40 minutes at $37^{\circ} \mathrm{C}$, and the remaining large aggregates were eliminated through a nylon filter ( $40 \mu \mathrm{m}$ diameter). The crude cell suspension was recovered by centrifugation at $450 \mathrm{~g}$ for 25 minutes at $4^{\circ} \mathrm{C}$. Cells were then washed twice in Hanks's balanced salt solution resuspended in phosphate buffered saline, $\mathrm{pH} 7 \cdot 4$, enriched with $1 \%$ bovine serum albumin and $0.1 \%$ sodium azide (PBS). The suspension was adjusted at $10^{7} / \mathrm{ml}$, and cell viability was evaluated by the eosin-Y exclusion dye test.

Immunofluorescence studies. Cell subsets were identified by labelling with monoclonal antibodies and flow cytometry analysis. ${ }^{9}$ Briefly, $10^{6}$ cells were incubated for 30 minutes at $4^{\circ} \mathrm{C}$ with each monoclonal antibody at the optimal dilution; they were then washed twice in PBS. The fluorescent conjugate was added for another 30 -minute period at $4^{\circ} \mathrm{C}$ and the cells were washed once. They were run in a $50 \mathrm{H}$ Cytofluorograf (Ortho Instruments, Westwood, USA) interfaced to a MINC 11-23 computer $^{10}$ to provide simultaneous measurements of the scattered light and the green fluorescence of each cell, as it passed through the $488 \mathrm{~nm}$ line of an argon-ion laser (total power $=5$ watts). Simultaneous measurements of the forward angle scatter (FAS, proportional to cell diameter) and the right-angle scatter (RAS, proportional to cell volume and protein content) were used to identify synovial fluid leucocytes. Two clusters of dots were observed (Fig.1), corresponding to lymphocytes and polymorphs respectively, as

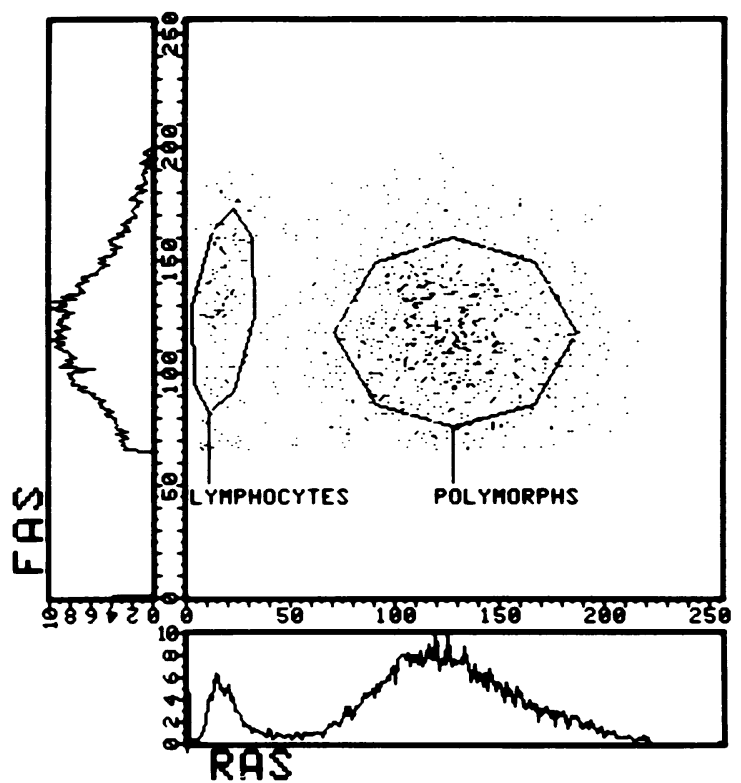

Fig. 1 Light scatter analysis of synovial fluid leucocytes. $\mathrm{RAS}=$ right angle scattered light . FAS = forward angle scattered light. 
shown by cytological examination of sorted cells; between these two clusters a few monocytes could be identified by staining with OKM1 antibody. ${ }^{11}$ Furthermore, May-Grünwald-Giemsa staining of the whole suspension never showed plasma cells. Monoclonal antibodies were used for the determination of T cells (OKT3), suppressor/cytotoxic cells (OKT8), and helper/inducer cells (OKT4). Activated T cells were enumerated with OKIa 1 antibody and OKT10 positive cells. ${ }^{7}$ All these antibodies were purchased from Ortho Pharmaceutical Corporation (Aubervilliers, France). They were revealed by a fluoresceinconjugated goat anti-mouse IgG (Nordic, Tebu, Paris) which had been previously absorbed with human lymphocytes and chloroformate-polymerised human immunoglobulins. Fluorescence profiles were determined for each monoclonal antibody reacting with the cells in the lymphocyte cluster (small lymphocytes and/or large lymphoblastoid cells). Percentages of fluorescent cells were evaluated by setting a threshold which separated stained cells from negative ones. This threshold was chosen by running cells treated with the fluorescent conjugate alone. About 10000 cells were counted for each sample.

Determination of cellular content of DNA and $R N A$. For simultaneous measurements of cellular DNA and RNA we used a minor modification of the acridine-orange staining procedure in which RNA fluoresces red and DNA green. ${ }^{12,13}$ Aliquots of cells $\left(10^{6}\right.$ in $\left.0.1 \mathrm{ml}\right)$ were made permeable with $0.2 \mathrm{ml}$ of a nonionic detergent at a low $\mathrm{pH}$ (hydrochloric acid $0.05 \mathrm{M}$, sodium chloride $0.15 \mathrm{M}$, Triton $\mathrm{X} 100$ $0 \cdot 1 \%$ ). After 45 seconds $0.6 \mathrm{ml}$ of a solution containing $0 \cdot 2 \mathrm{M}$ disodium hydrogen phosphate, $0 \cdot 1$ citric acid buffer ( $\mathrm{pH} 6 \cdot 0$ ), $1 \mathrm{mM}$ sodium EDTA, $0 \cdot 15 \mathrm{M}$ sodium chloride, and acridine orange at $15 \mu \mathrm{g} / \mathrm{ml}$ was added. Fluorescence was measured within 10 minutes. Two bands of emitted fluorescence were simultaneously measured for each cell as it passed through the focused laser. The green fluorescence signal corresponding to DNA content was stored both in a 'peak mode' and in an 'area mode' in order to allow distinction between doublets and cells showing $4 \mathrm{n}$ DNA contents. The red fluorescent signal, corresponding to RNA content, was stored simultaneously in an 'area mode'. After the exclusion of doublets the correlated distribution of DNA and RNA content per cell was displayed on the screen. From this cytogram we could determine the distribution of cells within the phases of the cell cycle as already described. ${ }^{14}$ Analysis of the RNA content of cells within the G0/G1 phase was done by setting a window around the region corresponding to $2 n$ DNA content of cells. Histograms were generated from each of these regions. For each sample about 10000 cells were analysed.

\section{Results}

Pattern of DNA content in rheumatoid-arthritis synovial fluid lymphocytes (RA-SFL). The DNA of the total lymphocytes from synovial fluid displayed the same distribution (Fig. 2A) as that of normal peripheral blood lymphocytes (PBL) with a high peak corresponding to the $\mathrm{G} 0 / \mathrm{G} 1$ phase. The second peak corresponded to cells in the $\mathrm{G} 2+\mathrm{M}$ phase. The part of the histogram between these 2 phases corresponded to cells progressing through the $\mathrm{S}$ phase. For the calculation of the relative percentages of $\mathrm{G} 0 / \mathrm{G} 1$ and $\mathrm{S}+(\mathrm{G} 2+\mathrm{M})$ phases, the limit of the $\mathrm{G} 0 / \mathrm{G} 1$ phase was fixed at the end of the decreasing part of the peak, assuming symmetry under our staining conditions. Eleven samples of RA-SFL were evaluated: 6 out of 11 showed percentages of dividing cells varying from $2 \cdot 2$ to $7 \cdot 2 \%$, as compared with less than $1 \%$ in the other 5 patients and in normal blood (Table 2).

Patterns of RNA content in RA-SFL. Measurements of RNA content were done on lym-

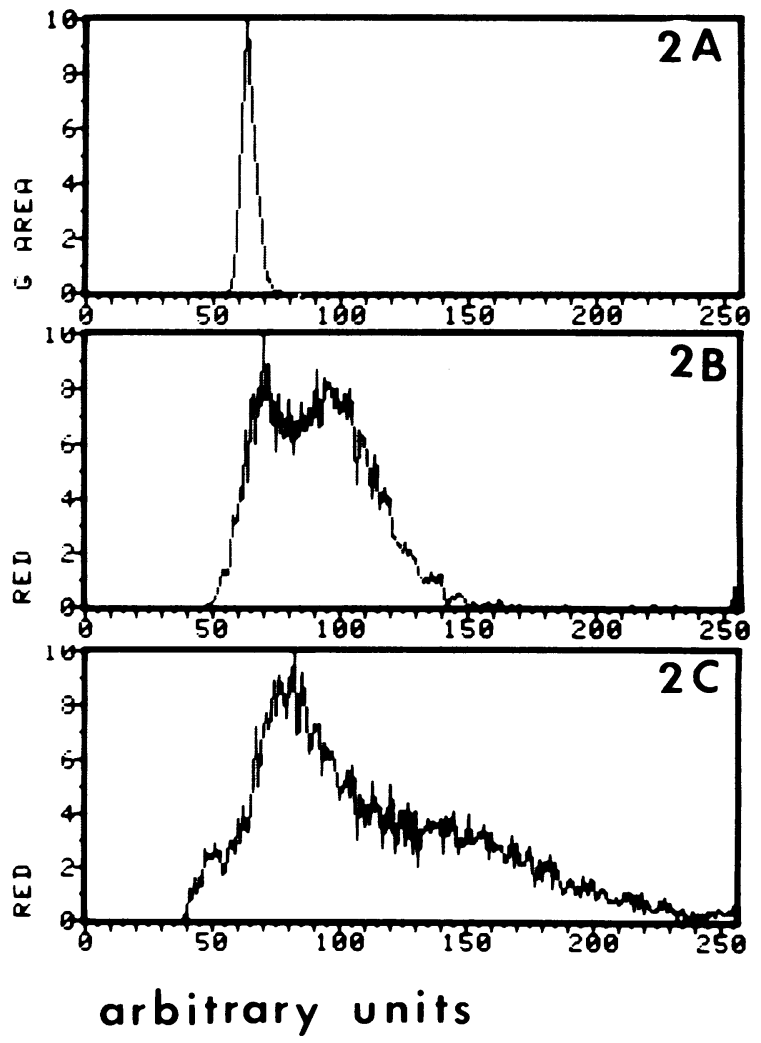

Fig. 2 Distribution histograms of DNA (2A) and RNA contents (2B and $2 \mathrm{C}$ ) from different cell suspensions. 
Table 2 DNA and RNA contents of RA-SFL

\begin{tabular}{lll}
\hline Patient & $\begin{array}{l}\text { RNA content } \\
\text { (units) }\end{array}$ & $\begin{array}{l}\text { Percentage } \\
\text { dividing cells } \\
(\%)\end{array}$ \\
\hline 1 & 46 & $3 \cdot 6$ \\
2 & 64 & $7 \cdot 2$ \\
3 & 52 & $3 \cdot 0$ \\
4 & 54 & $0 \cdot 8$ \\
5 & 90 & $0 \cdot 7$ \\
6 & 77 & $0 \cdot 9$ \\
7 & 53 & $4 \cdot 3$ \\
8 & 65 & $3 \cdot 2$ \\
9 & $89 / 52 \dagger$ & $0 \cdot 5$ \\
10 & 67 & $0 \cdot 5$ \\
11 & 63 & $2 \cdot 2$ \\
\hline
\end{tabular}

* RNA content is measured by the length of the interval below the median of the distribution histogram. The range of normal PBL is 18 to 48 units.

†This patient was evaluated twice, at a 3-month interval.

phocyte clusters in comparison with DNA measurements. The frequency histograms were recorded for cells in the G0/G1 phase of the cell cycle, as explained above in 'Materials and methods'. The shape of distribution histograms was either bimodal (Fig. 2B), as reported for lymphocytes from normal blood, or unimodal (Fig. 2C). Lymphocyte activation causes the RNA cell content to increase, as shown by a shift to the right on the histogram. Since a slight shift of the origin of the RNA histogram may also occur despite daily calibration, we chose to evaluate RNA content in arbitrary units (number of channels given by the cytofluorograph) as the length of the interval below the median: the longer the interval, the higher the RNA content of nondividing lymphocytes.

As shown in Fig. 3, the RNA contents of RA-SFL varied from 46 to 90 units (mean $\pm S D=64 \pm 14$ ), compared with 18 to 48 (mean $\pm \mathrm{SD}=35 \pm 9$ ) in normal blood, indicating the existence of activated nondividing lymphocytes in the synovial fluid from RA patients. Higher increases of RNA content were observed in patients $5,6,9$, and 10 with lower percentages of dividing cells (Table 2).

Relationship of RNA cell content with clinical status and biological parameters. The highest RNA contents of SFL were found in patients 5, 6, and 10 with a clinical status of active disease: classical RA ( 7 to 9 ARA criteria) and functional class III according to the Steinbrocker classification. They also had a high ESR, high CIC levels, and high titres of RF (Table 1).

Patient 9 was evaluated twice at a 3-month interval. She was not receiving treatment. Disease activity showed no appreciable change, and her RNA content decreased from 89 to 52 units but remained above the highest values observed in normal PBL.

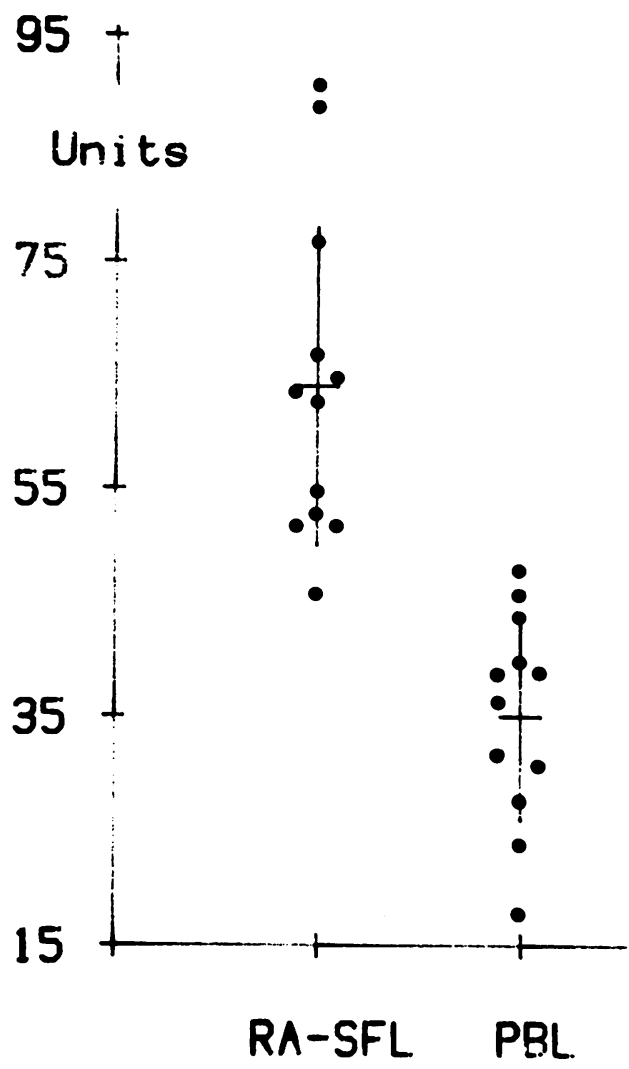

Fig. 3 Distribution of RNA contents in nondividing cells from peripheral blood of control subjects (PBL), and from synovial fluid of patients with rheumatoid arthritis (RA-SFL).

T lymphocyte subsets in RA-SFL. T cell subsets were evaluated for 5 patients on lymphocyte cluster; for 3 of them the determination was made separately on small and large lymphocytes (Table 3 ).

Percentages of OKT3 positive small lymphocytes were similar to those of normal blood. OKT4 and OKT8 positive cell percentages showed important individual variations. However, OKT4/OKT8 ratios were decreased in 4 out of 5 cases- 0.69 to $1 \cdot 46$. In a comparison of large lymphoblasts and small lymphocytes one patient showed a lowered OKT4/OKT8 ratio (1.03) for large lymphoblasts as compared with small lymphocytes $(2 \cdot 72)$.

Presence of 'activation antigens' on RA-SFL. RA-SFL showed a definite increase in the percentage of Ia-like antigen (OKIa 1) positive small lymphocytes: $27 \% \pm 5$ (Table 3 ). For 2 out of 3 patients percentages of Ia-like positive large lymphoblastoid cells were still higher-51 and $90 \%$. 
Table 3 T lymphocyte subsets and percentages of Ia-like positive cells in RA-SFL determined by monoclonal antibodies

\begin{tabular}{|c|c|c|}
\hline & $\begin{array}{l}\text { Small lymphocytes } \\
\text { (patients } 3,4,6,8,11 \text { ) }\end{array}$ & $\begin{array}{l}\text { Large lymphoblasts* } \\
\text { (patients } 3,8,11 \text { ) }\end{array}$ \\
\hline OKT3† & $82 ; 68 ; 52 ; 67 ; 80$ & $68 ; 25 ; 76$ \\
\hline OKT4† & $39 ; 37 ; 59 ; 50 ; 48$ & $44 ; 18 ; 87$ \\
\hline OKT8† & $37 ; 31 ; 86 ; 18 ; 39$ & $30 ; 17 ; 78$ \\
\hline $\begin{array}{l}\text { OKT4/OKT8 } \\
\text { ratio }\end{array}$ & $\begin{array}{l}1 \cdot 07 ; 1 \cdot 19 ; 0 \cdot 69 ; \\
2 \cdot 72 ; 1 \cdot 24\end{array}$ & $1 \cdot 46 ; 1 \cdot 03 ; 1 \cdot 11$ \\
\hline $\mathrm{OKI}_{\mathrm{a} 1}{ }^{\dagger}$ & $21 ; 25 ; 35 ; 28 ; 26$ & $35 ; 51 ; 90$ \\
\hline
\end{tabular}

* Percentages are those of positive cells for one or another OKT monoclonal antibody measured inside selected windows (see text, 'Materials and methods'). Numbers between brackets are those of patients indicated in Table 1.

† Positive cells for the relevant monoclonal antibody.

Monoclonal antibody OKT10 has been used in patient 6 , and a high number of OKT10 positive cells was found $-43 \%$. No large cells were noted in this patient, and $35 \%$ of small lymphocytes expressed Ia-like antigen.

We did not determine which SFL $\mathrm{T}$ cell subset possessed Ia-like antigens. However, in 3 cases out of 8 the addition of percentages of cells expressing either OKT4 or OKT8 and Ia-like antigen were higher than 100 , suggesting the existence of doublylabelled cells.

\section{Discussion}

The present study was designed to assess lymphocyte activation in RA-SF. A well-documented marker of $T$ cell activation is the expression of Ia-like antigens, which increases in peripheral blood after immunisation as well as in certain diseases. ${ }^{15}$ High percentages of SF OKIa 1 positive cells were found in the 5 patients studied, in agreement with other reports on SF and synovial tissue. ${ }^{16,17}$ The much lower increase of Ia-like antigen positive $T$ cells reported in peripheral blood ${ }^{16}$ provides further evidence that synovial tissue is the main site of lymphocyte activation in RA.

Alterations of $\mathrm{T}$ cell regulatory functions, possibly reflected by an imbalance of $T$ cell subsets, have been reported in several connective tissue diseases, including RA. Janossy et al. ${ }^{2}$ reported a low percentage of OKT8 positive cells in synovial membrane, in contrast to our own results and those of Fox et al. ${ }^{1}$ showing decreased percentages of OKT4 positive cells and low OKT4/OKT8 ratios in RA-SF. Changes among peripheral blood $T$ cell subsets do not parallel those of SF. ${ }^{1,}{ }^{18}$ Further studies are needed to " assess the possible functional significance of those observations.

Simultaneous measurements of the RNA and
DNA content of the same lymphocytes not only provide accurate estimates of the number of cycling cells but permit us to identify a subset of cells with increased RNA content in the G0/G1 phase. In-vitro activation of $T$ lymphocytes was recently shown to require at least 2 sequential sets of signals. The first is provided by the mitogen or the antigen which, along with interleukin-1, makes the resting G0 cell enter the G1 phase. A second signal, interleukin-2, is required for the cell to proceed to the $S$ phase.${ }^{19} \mathrm{High}$ percentages of lymphocytes with raised DNA content were found in 6 out of 11 patients, in keeping with the increased ${ }^{3} \mathrm{H}$-thymidine incorporation into unstimulated lymphocytes reported by Corrigall and Panayi ${ }^{20}$ However, the most striking observation is the high RNA content of SF lymphocytes without concomitant increase of DNA content in patients 5 , 6,9 , and 10 . Such dissociation clearly demonstrates a G1/S block. A comparable block was recently reported in some patients with systemic lupus erythematosus by Alarcon-Segovia et al. ${ }^{21}$ These authors suggested that anti-DNA antibodies might have a DNA blocking potential. Our data do not suggest that a similar regulatory pathway occurs in RA, since the 4 patients with a G1/S block had no detectable ANA, whereas the 4 other patients with ANA $(3,7,8$, and 11) had increased percentages of dividing SF lymphocytes, ranging from $2 \cdot 2$ to $4 \cdot 3$ (Table 2). Three of the 4 patients with G1/S block had high ESR, circulating immune complexes, and RF titres. Therefore no direct relationship between the usual parameters of disease activity and SF lymphocyte RNA and DNA contents can be drawn from the present study, but a larger series of patients would be needed to allow a definite conclusion in this respect. Finally, the simultaneous determination of RNA and DNA content and that of differentiation antigens of SF lymphocytes showed markers of lymphocyte activation in all cases with an unexpected G1/S block in 4 out of 11 patients. Such findings might be important for the assessment of immunomodulating agents in the treatment of RA.

The authors are grateful to Dr E. Vignon for allowing the study of his patients, They wish to thank Miss M. Comte for expert technical assistance and also Miss S. Alfano and Miss C. Lebeslour for typing the manuscript. They are indebted to $P$. Bouic for reviewing the English in the manuscript.

\section{References}

1 Fox R I, Fong S, Sabharval N, Cartens S A, Kung P C, Vaughan J H. Synovial fluid lymphocytes differ from peripheral blood lymphocytes in patients with rheumatoid arthritis. $J$ Immunol 1982; 128: 351-4.

2 Janossy G, Panayi G, Duke O, Bofill M, Poulter L W, Goldstein G. Rheumatoid arthritis: a disease of T lymphocyte-macrophage immunoregulation. Lancet 1981; ii: 839-42. 
3 Biberfeld G, Nilsson E, Biberfeld P. T lymphocyte subpopulations in synovial fluid of patients with rheumatic diseases. Arthritis Rheum 1979; 22: 978-82.

4 Sakane T, Takada S, Murakawa Y, Kotani H, Honda M, Ueda $Y$. Analysis of suppressor $T$ cell function in patients with rheumatoid arthritis: defects in production of and responsiveness to concanavalin A-induced suppressor T cells. J Immunol 1982; 129: 1972-7.

5 Chattopadhyay C, Chattopadhyay H, Natvig J B, Michaelsen T E, Mellbye $O \mathrm{~J}$. Lack of suppressor cell activity in rheumatoid synovial lymphocytes. Scand J Immunol 1979; 10: 309-16.

6 Chattopadhyay C, Chattopadhyay H, Natvig J B, Mellbye O J. Rheumatoid synovial lymphocytes lack concanavalin A-activated suppressor cell activity. Scand J Immunol 1979; 10: 479-86.

7 Hercend T, Ritz J, Schlossman S F, Reinherz E L. Comparative expression of $\mathrm{T} 9, \mathrm{~T} 10$ and Ia antigens on activated human $\mathrm{T}$ cell subsets. Hum Immunol 1981; 3: 247-59.

8 Ropes M W, Bennett G A, Cobb S, Jacox R, Jessar R A. Revision of diagnostic criteria for rheumatoid arthritis. Bull Rheum Dis 1958; 9: 175-6.

9 Hoffman R A, Kung P C, Hansen W P, Goldstein G. Simple and rapid measurement of human $\mathrm{T}$ lymphocytes and their subclasses in peripheral blood. Proc Natl Acad Sci USA 1980; 77: 4914-7.

10 Cordier G, Mornex J F, Lefebvre R, Revillard J P. Analyse multiparamétrique des alvéolites lymphocytaires par cytofluorométrie et anticorps monoclonaux. Communication at Quo Vadis Symposium. "Cytofluorométrie et anticorps monoclonaux pour le suivi des thérapeutiques." Montpellier, October 1982.

11 Breard J, Reinherz E L, Kung P C, Goldstein G, Schlossman S F. A monoclonal antibody reactive with human peripheral blood monocytes. J Immunol 1980; 124: 1943-8.

12 Darzynkiewicz Z, Traganos F, Sharpless T K, Melamed M R. Lymphocyte stimulation: a rapid multiparameter analysis. Proc Natl Acad Sci USA 1976; 73: 2881-4.
13 Traganos F, Darzynkiewicz Z, Sharpless T K, Melamed M R. Simultaneous staining of ribonucleic and deoxyribonucleic acids in unfixed cells using acridine orange in a flow cytometric system.J Histochem Cytochem 1977; 25: 46-56.

14 Pacheco Y, Cordier G, Perrin-Fayolle M, Revillard J P. Flow cytometry analysis of $\mathrm{T}$ lymphocytes in sarcoidosis. Am J Med 1982; 73: 82-8.

15 Yu D T Y, Winchester R J, Fu S M, Gibofsky A, Ko H S, Kunkel H G. Peripheral blood la-positive $T$ cells. Increase in certain diseases and after immunization.J Exp Med 1980; 151: 91-100.

16 Burmester G R, Yu D T Y, Irani A M, Kunkel H G, Winchester $R \mathrm{~J}$. Ia $+\mathrm{T}$ cells in synovial fluid and tissues of patients with rheumatoid arthritis. Arthritis Rheum 1981; 24: 1370-6.

17 Forre O, Dobloug J H, Natvig J B. Augmented numbers of HLA-DR positive $T$ lymphocytes in the synovial fluid and synovial tissue of patients with rheumatoid arthritis and juvenile rheumatoid arthritis. In vivo-activated $\mathrm{T}$ lymphocytes are poten stimulators in the mixed lymphocyte reaction. Scand J Immunol 1982; 15: 227-31.

18 Forre O, Thoen J, Dobloug J H, et al. Detection of T lymphocyte subpopulations in the peripheral blood and the synovium of patients with rheumatoid arthritis and juvenile rheumatoid arthritis using monoclonal antibodies. Scand J Immunol 1982; 15: 221-6.

19 Stadler B M, Oppenheim J J. Human Interleukin-2: biological studies using purified $11-2$ and monoclonal anti-11-2 antibodies. Lymphokines 1982; 6: 117-35.

20 Corrigall V M, Panayi G S. Lymphocyte studies in rheumatoid arthritis. III. A comparative study of the responses of peripheral blood and synovial fluid lymphocytes to phytomitogens. Scand J Rheumatol 1979; 8: 10-6.

21 Alarcon-Segovia D, Llorente L, Fishbein E, Diaz-Jouanen E. Abnormalities in the content of nucleic acids of peripheral blood mononuclear cells from patients with systemic lupus erythematosus. Relationship to DNA antibodies. Arthritis Rheum 1982; 23: 304-17. 